\title{
THE REPRESENTATION OF HEALTH MINISTER IN HANDLING COVID-19 IN INDONESIA: A CRITICAL DISCOURSE ANALYSIS
}

\author{
${ }^{1}$ Yulia Anggraeni*, ${ }^{1}$ Rosaria Mita Amalia \\ ${ }^{1}$ Univeritas Padjadjaran, Indonesia \\ *Corresponding Author: yulia19003@gmail.com
}

\begin{abstract}
COVID-19 outbreaks that threaten human health have become a pandemic. As the Health Minister in Indonesia, the actions were taken by the Letjen TNI (Purn) Dr. dr. Terawan Agus Putranto, Sp. Rad. (K) in handling this pandemic is in the spotlight. There are so many media that providenews related to the efforts of the Health Minister in handling this case, one of which is The Jakarta Post. This study aims to describe the representation of Mr. Terawan as Health Minister in handling COVID-19 cases in Indonesia in The Jakarta Post. Critical Discourse Analysis as an approach is used in his study. The data are the articles in The Jakarta Post related to Mr. Terawan in handling the COVID-19 cases in Indonesia. The data is analyzed using a discursive strategy. According to Wodak\& Mayer (2001), there are five strategies in Discursive, but this study only applies two strategies, namely Nomination Strategies and Predication Strategies. The findings in this study are; (1) four nomination strategies areused by The Jakarta Post. They are deixis, proper names, professional anthroponym, and nouns. The Jakarta Post uses the nomination strategy to avoid repetition of the same proper name, to show the readers which person becomes the center of the text, and to describe and report Mr. Terawan's action regarding his job as Health Minister; (2) The Jakarta Post gave a negative attribute to the performance of Mr. Terawan as a Health Minister in handling with COVID-19 cases.The Jakarta Post's belief that Mr. Terawan has performed badly as a Health Minister in handling the COVID-19 case and The Jakarta Post sees Mr. Terawan as a careless person in the case.
\end{abstract}

Keywords: COVID-19; Critical Discourse Analysis; Discursive Strategies; Health Minister of Indonesia

\begin{abstract}
ABSTRAK
Wabah COVID-19 yang mengancam kesehatan manusia telah menjadi sebuah pandemi. Sebagai Menteri Kesehatan di Indonesia, tindakan yang telah diambil oleh Letjen TNI (Purn) Dr. dr. Putranto, Sp. Rad. (K) dalam menangani pandemi ini menjadi sebuah sorotan. Banyak sekali media memberikan berita terkait upaya dari Menteri Kesehatan dalam menangani kasus ini, salah satunya adalah dalam The Jakarta Post. Penelitian ini sendiri bertujuan untuk menggambarkan representasi sosok Bapak Terawan sebagai Menteri Kesehatan dalam menangani kasus COVID-19 di Indonesia dalam The Jakarta Post. Penelitian ini menggunakan Analisis Wacana Kritis (AWK) sebagai pendekatan. Data dalam penelitian ini adalah artikelartikel di The Jakarta Post terkait dengan Menteri Kesehatan dalam menangani kasus COVID19 yang ada di Indonesia. Data dianalisis menggunakan Discursive Strategy. Ada lima strategi dalam Discursive ini, tetapi penelitian ini hanya menerapkan dua strategi, yaitu Nomination Strategies dan Predication Strategies. Temuan dalam penelitian ini dinataranya adalah; (1) ada empat Nomination Strategies yang digunakan oleh The Jakarta Post, yaitu deixis, proper name, professional anthroponym, and noun; (2) The Jakarta Post memberikan atribut negative terhadap kinerja dari bapak Terawan sebagai Menteri Kesehatan dalam menangani kasus
\end{abstract}


Celtic: A Journal of Culture, English Language Teaching, Literature and Linguistics

Vol. 7, No. 2, December 2020.

E-ISSN: 2621-9158 P-ISSN:2356-0401

http://ejournal.umm.ac.id/index.php/celtic/index

COVID-19. The Jakarta Post menganggap bahwa bapak Terawan menangani kasus COVID-19 dengan buruk dan melihat Mr. Terawan sebagai orang yang ceroboh dalam kasus ini.

Keywords: COVID-19; Kementerian Kesehatan Indonesia; Strategi Diskursi; Wacana Analisis Kritis

\section{INTRODUCTION}

The coronavirus disease (COVID-19) becomes a pandemic today, as reported by kompas.com (2020), the Directorate General of World Health Organization (WHO), Tedros Adhanom Ghebreyesus officially announced the COVID-19 outbreak as a global pandemic. The COVID-19 was first discovered in Wuhan a city in China. The first patient suspected of being infected with the coronavirus was a 55-year-old Wuhan citizen on November 17, 2019. However, the Chinese government only realized that they were facing this dangerous virus in early December 2019. As cited from hopkinsmedicine.org, coronavirus can spread very fast because it spreads when an infected person coughs or sneezes and the droplets of saliva or discharge from the nose. Therefore, WHO recommends wearing masks when leaving the house, doing physical distancing, and doing daily activities online from home.

Indonesia is one of the countries that has patients infected with the coronavirus. The President Joko Widodo on March 2, 2020 announced the first patient who infected the coronavirus in Indonesia. Since then, government policies in tackling this pandemic were made, such as requiring using masks, conducting large-scale social restrictions (PSBB), work from home, and the other things deemed necessary to reduce the spread of the coronavirus. This COVID-19 issue is reported by most of the mass media in Indonesia. The way the government handle the coronavirus case has also come under the spotlight of many news media. One of the mass media that provide that news is The Jakarta Post. The Jakarta Post is a newspaper based in Indonesia which is a member of the Asia News Networkthat usesthe English language. The target of the newspaper is not only Indonesian but also it is targeted to foreigners. According to Kurniawan \&Utami (2017), the way the mass media construct someone's figure relates to representation. In discourse analysis perspective, the people, places, or social practices that express in a language is representation (Van Dijk as cited from Kurniawan \&Utami, 2017). Based on the background, this research aims to describe the representation of Mr. Terawan's figure as a Health Minister in handling the COVID-19 case in Indonesia using the Critical Discourse Analysis (CDA) approach and using Discursive Strategies for the analysis.Thus The Jakarta Post's representation of Mr.Terawan's performance as minister of health in dealing with COVID-19 in Indonesia can be seen in the result of data analysis.

Several previous types of research also used the Critical Discourse Analysis (CDA) approach and using Discursive Strategies for the analysis. Purwanto (2017) conducted the research to see how the media social give the impact of written expression toward the people who read it. The data of his research were Ridwan Kamil's media social, when Ridwan Kamil became Mayor of Bandung. The results of this research show that Ridwan Kamil used all discursive strategy in his status update. The result also shows Ridwan Kamil's status update gives some aspects that effect readers. The analysis of two discursive strategies which is nomination and predication 
strategies also used by Kurniawan \&Utami (2017) to analyze the representation of Jokowi's figure as the governor of Jakarta, the presidential candidate, and the President of Indonesia in the Jakarta Post. The findings of the research found that Jokowi has a support from The Jakarta Post for his performance as a leader which in line with The Jakarta Post values, but Jokowi doesn't have a support from The Jakarta Post on the KPK's topic, as its conduct is seen to undermine the agenda of the Jakarta Post that promotes the anti-corruption movement.

A Discourse analysis is study that analyze language used in written or oral form. In sociology, discourse is relationship between context social and language used. According to Brown \& Yule (2012), sociolinguistics, psycholinguistics, philosophical linguistics and computational linguistics can be described in discourse analysis. Putri et al. (2017) also discuss that discourse is a place to express opinions and thoughts. Discourse can also cover other studies, such as communication, information, politics, and literature. The fact that there is no such thing as neutrality in a text is also emphasized in Critical Discourse Analysis (Rahardi\& Amalia, 2019). Discourse analysis has been seen as an alternative to other social activities, including advertisements, television, comedy, books, class problems, and even sexism (Chaerani\&Junaidi, 2019). Meanwhile, Critical Discourse Analysis (CDA) is different from discourse analysis. Critical Linguistic approach focus onthe analysis of language concerning ideology. The relations between discourse and power relations, ideologies, institutions, or social identities is the focus of the critical tradition of social analysis into language studies and contributes to critical social analysis that brought by Critical Discourse Analysis (Gee \&Handford, 2012).Akinwotu (2014) stated that the position of CDA is that a proper analysis of discourse should take into account not only the social function of language in society but also the context under which discourse was produced.

There is difference between Discourse Analysis and Critical Discourse Analysis. The difference isthe focus on both studies, the Discourse Analysis focuses on the message's structure in communication or an investigationconcerning to various functions (pragmatics), but Critical Discourse Analysis focus on process to explain a text as social reality and being reviewed by a person or a group of dominant tendency who has a specific purpose. Historical, context, action, power, and ideologyare some characteristics of Critical Discourse Analysis. However, Discourse Analysis and Critical Discourse Analysis also have similarity, that is, the object under study is the language used in a written or oral text.

In Critical Discourse Analysis, there are five common features can be identified. They are; (1) The Character of Socialand Cultural Processes and Structures is Partly Linguistic - Discursive; (2) Discourse is Both Constitutive and Constituted; (3) Language use should be Empirically Analysed within its Social Context; (4) Discourse Functions Ideologically; (5) Critical Research (Phillips \& Jorgensen, 2002). According to Wodak\& Meyer (2009), discursive strategy means an elaborate and systematic way of using language to reach a particular social, political, psychological, or linguistic goal. Nomination, Predication, Argumentation, Perspectivation, and Intensification are strategies in the Discursive. Power relations of the public figure have strong connections to the five discursive strategies. This study analyzes the nomination and predication strategies only. 
The nomination is the first discursive strategies. This is a strategy in using linguistic devices such as membership categorization devices such as deixis, anthroponym, and metonymic to refer to persons, things, places, or events (Kurniawan \&Utami, 2017). The second strategy is Predication. A strategy in attaching persons, animals, or objects with some qualities or characteristics is called a Predication strategy. In this strategy, representing social actors can be analyzed as more or less positively or negatively (Reisigl\&Wodak, 2001). As discussed by Purwanto (2017), the third strategy is argumentation. This strategy aims to see which positive and negative attributions are justified. Public opinion positively and negatively depends on the intention of the user. Next, there is the Perspectivation strategy which is expressing involvement positioning the speaker's point of view. This strategy will help to separate and pick the correct stand for the real user, as the language itself can intensified and mitigated accordingly (Renkema cited in Purwanto, 2017).

The research question in this study is, how is the Representation of Mr. Terawan's figure in handling the COVID-19 case in The Jakarta Post? The News article about Mr. Terawan as Health Minister in handling the COVID-19 case will be analyzed using discursive strategies (Nomination and predication strategies). The data will be analyzed to find out Mr. Terawan's positive or negative attributions.According to Utama et al. (2020), News discourse does not only represent the reported event but it also contains a particular hidden ideology which is shared through language as its main instrument. Thus, by seeing the representation of Mr. Terawan in The Jakarta Post, Mr. Terawan's performance as a health minister can be seen from the news made by The Jakarta Post.

\section{METHOD}

This research applies descriptive qualitative research. The qualitative research will show the result in form of an explanation of words thatis supported by data. Bogdan and Taylor in Moleong (2004) stated that the details investigated by the researchers in the descriptive qualitative analysis was in the form of oral or written words. This study is considered qualitative because it concerns non-numeric data and is descriptive since it intends to objectively explain the facts of the analysis based on the real facts of the analysis. Critical Discourse Analysis (CDA) is used as an approach for this research and discursive strategies theory is used to analyze the data.

The document is used as an instrument in this research. Documents consist of public and private documents collected by observational researchers on the web or research participants and can contain newspapers, minutes of sessions, personal journals, and letters.(Creswell, 2012). The main source data of this research are news article in The Jakarta Post. In the first steps, the researchers try to select the news article about Mr. Terawan as Health Minister in Handling The COVID-19 case. The researchers found eight articles related to the issue in The Jakarta Post. thesearticles are published by The Jakarta post around March to June 2020. Second, the researchersanalyze the data usingthe discursive strategies theory by Wodak\& Mayer (2001). The last, the researchers describe the result of the analysis.

\section{FINDINGS AND DISCUSSION}

This study is focused on two discursive strategies, namely nomination and predication used by The Jakarta Post to represent Health Minister in Handling the 
COVID-19 case in Indonesia. Based on the analysis, the researchers found that the Nomination strategy used by The Jakarta Postis deixis, proper name, andanthroponyms. Meanwhile, the predication strategy used by The Jakarta Postisan explicit predicate and adjective predicate strategies. Two explicit predicates contain evaluative attributions of negative, but explicit predicates that contain evaluative attributions of positive were not found in this study. The adjective predicate strategy that contains evaluative attributions of negative used by The Jakarta Post in articles about Mr. Terawan in handing COVID19 cases.

The discussion of this study is divided into two-part, they are nomination strategy and predication strategy.

\section{Nomination Strategies}

The use of the Nomination strategy shows how The Jakarta Post mention of Mr. Terawan in different things such as to show the center of the text or to describe and report Mr. Terawan's action regarding his job as Health Minister. According to the analysis of the articles in The Jakarta Post about Mr. Terawan in the COVID-19 case, the first time facing COVID-19 in Indonesia, large-scale social restrictions (PSBB) issue, and thenew normal issue, four nomination strategies are used by The Jakarta Post. They are deixis, proper names, professional anthroponym, and nouns. Among all nomination strategies, the proper name becomes the most frequent nomination strategy used by The Jakarta Post. The analysis of nomination strategies is shown below.

The Jakarta Post uses deixis to avoid repetition of the same proper name throughout the text. The deixis that used is 'he' and 'his'.

[1] Terawan said he wanted people to wash after activities in public, including after picking up trash in public facilities.

[2] Health Minister TerawanAgusPutranto has been criticized for his lack of transparency and sluggish efforts to test for and trace the novel coronavirus disease (COVID-19) while other countries have scrambled to improve public health measures to contain the global outbreak.

The Jakarta Post only uses deixis 'he' and 'his' to refer Mr. Terawan. The Jakarta Post does not use deixis 'we' which indicating a collective sense of belonging between the Jakarta Post and Mr. Terawan or 'they' in the context ofcomparing 'we' and 'they' showing exclusion, that means a position between The Jakarta Post and Mr. Terawan is close or distant (Kurniawan and Utami, 2017).

The proper name is also used to refer to Mr. Terawan. The word Terawan is employed to refer to the Health Minister to show to the readers which person becomes the center of the text. According to Kurniawan \&Utami (2017), the use of the nomination strategy also indicates that the Jakarta Post tries to avoid ambiguity. The use of the proper name is shown in [3] and [4].

[3] In a ministerial decree issued on Saturday, Terawan detailed how offices and manufacturers should operate during the large-scale social restrictions (PSBB).

[4] "However, it's impossible to impose restrictions on workplaces forever. We should keep the wheels of our economy running," Terawan said in a statement on the Health Ministry's official website. 
The professional anthroponyms also applied by The Jakarta Post in purpose to describe and report Mr. Terawan's action regarding his job as Health Minister. Examples of the use of professional anthroponyms are shown below.

[5] While declaring the country virus-free and asking people to keep praying, the minister did not carefully trace potential cases despite reports that certain foreign travelers who had transited in the country had later tested positive for the virus.

[6] Health MinisterTerawanAgusPutranto has issued new health protocols for workplaces to usher in the so-called "new normal" even as the number of confirmed COVID-19 cases continues to rise.

\section{Predication Strategies}

According to the analysis of the articles in The Jakarta Post about Mr. Terawan, predications strategies can represent The Jakarta Post's judgment on Mr. Terawan's figure. The predications are used to see Terawan's roles as Health Minister in handling the COVID-19 case. They are further classified based on positive and negative tendencies.

The predications are classified into six predication strategies, namely explicit predicate, adjective, relative clause, infinitive phrase, prepositional phrase, and hyperbole (Kurniawan \&Utami, 2017). The explicit predicate and adjective predicate strategies found in The Jakarta Post's articles about Mr. Terawan in handling the COVID-19 case. Two explicit predicates contain evaluative attributions of negative, but explicit predicates that contain evaluative attributions of positive were not found in this study. The examples of the explicit predicate are shown in [7] and [8].

[7] Health Minister TerawanAgusPutranto has been criticized for his lack of transparency and sluggish efforts to test for and trace the novel coronavirus disease (COVID-19) while other countries have scrambled to improve public health measures to contain the global outbreak.

[8] Health Minister TerawanAgusPutranto has issued new health protocols for workplaces to usher in the so-called "new normal" even as the number of confirmed COVID-19 cases continues to rise.

The predicate 'his lack of transparency and sluggish efforts' in [7] projects The Jakarta Post's belief that Mr. Terawan has performed badly as a Health Minister because of Mr. Terawan sluggish efforts in handling with COVID-19 cases in Indonesia. Meanwhile, in [8],The Jakarta Post seems to doubt the new normal proclaimed by the Health Minister. Two predicates above contain evaluative attributions of negative.

There were no adjective predicate strategies that contain evaluative attributions of positively used by The Jakarta Post. There is one adjective predicate strategy that contains evaluative attributions of negative used by The Jakarta Post about Mr. Terawan in handing COVID-19 cases. The adjective predicate strategies that contain evaluative attributions of negative are shown below.

[9] While declaring the country virus-free and asking people to keep praying, the minister did not carefully tracepotential cases despite reports that certain foreign travelers who had transited in the country had later tested positive for the virus. 
Anggraeni, Y., \& Amalia, R.M. (2020). The Representation of Health Minister in Handling Covid-19 in Indonesia: A Critical Discourse Analysis. Celtic: A Journal of Culture, English Language Teaching, Literature, \& Linguistics, 7(2), 208-215.

The negative representation shown in the articles due to The Jakarta Post gives the opinions and probability toward Mr. Terawan (Utama \& Amalia, 2019). The predicate 'did not carefully' as opinion shows that The Jakarta Post sees Mr. Terawan as a careless person for not responding to reports about the development of the coronavirus that may be spread from tourists who come to Indonesia.

From the analysis above, The Jakarta Post gave a negative attribute to the performance of Mr. Terawan as a Health Minister in handling with COVID-19 cases.

\section{CONCLUSION}

Based on the analysis of the articles in The Jakarta post related to Mr. Terawan in handling the COVID-19 case, four nomination strategies are found in this study. They are deixis, proper names, professional anthroponym, and nouns. The Jakarta Post uses deixis to avoid repetition of the same proper name throughout the text. The proper name uses to refer to the Health Minister to show the readers which person becomes the center of the text. Meanwhile, the professional anthroponyms also applied by The Jakarta Post in purpose to describe and report Mr. Terawan's action regarding his job as Health Minister. The explicit predicate and adjective predicate strategies are foundin The Jakarta Post's article about Mr.Terawan in handling the COVID-19 case. Two explicit predicates contain evaluative attributions of negative and one adjective predicate strategies that contain evaluative attributions of negative. Mr. Terawan's attributions of negative are; The Jakarta Post's belief that Mr. Terawan has performed badly as a Health Minister because of Mr. Terawan sluggish efforts in handling with COVID-19 cases in Indonesia; The Jakarta Post seems to doubt the new normal proclaimed by the Health Minister, and The Jakarta Post sees Mr. Terawan as a careless person for not responding to reports about the development of the coronavirus that may be spread from tourists who come to Indonesia.

\section{REFERENCES}

Akinwotu, S, A., (2014). A Comparative Study of the Discursive Strategies in the Media Interviews of Participants in the January 2012 Fuel Subsidy Removal Crisis in Nigeria. Journal of Arts and Humanities, 3(7), 21.

Brown, G. \& Yule, G. (2012). Discourse analysis. Cambridge University Press.

Chaerani, A. R., \& Junaidi, J. (2019). Does Diet Start Tomorrow? a Discourse Analysis of Self-Deprecating Humor Against Diet Culture in Diet Starts Tomorrow. Celtic: A Journal of Culture, English Language Teaching, Literature, \& Linguistics, 6(2), 51. https://doi.org/10.22219/celticumm.vol6.no2.51-62

Creswell, John, W. (2012). Educational research: planning, conducting, and evaluating quantitative and qualitative research. University of Nebraska-Lincoln.

Gee, J. \& Handford, M. (2012). The Routledge handbook of discourse analysis.

Kurniawan, E \&. Utami, Amalia Dwi. (2017). The Representation of Joko widodo's Figure in The Jakarta Post. Indonesian Journal of Applied Linguistics, 6(2), 341350.

Moleong. Lexy, J. (2004). Metodologi Penelitian Kualitatif(Edisi Revi). Bandung: Remaja Rosdakarya.

Phillips, L. \& Jorgensen, M. (2002). Discourse analysis as theory and method. London: SAGE. 
Celtic: A Journal of Culture, English Language Teaching, Literature and Linguistics

Vol. 7, No. 2, December 2020.

E-ISSN: 2621-9158 P-ISSN:2356-0401

http://ejournal.umm.ac.id/index.php/celtic/index

Purwanto, Y. (2017). Discursive Strategies on Ridwan Kamil's Status Update: a Critical Discourse Analysis. Humaniora, 8(2), 153. https://doi.org/10.21512/humaniora.v8i2.3893

Putri, A. G., Amalia, R. M., \& Pamungkas, K. (2017). Positive representation of women in Beyonce's song lyrics: Discourse analysis. 1st National Conference on Teachers' Professional Development, 87-95.

Rahardi, H. R., \& Amalia, R. M. (2019). Meme as political criticism towards 2019 Indonesian general election: A critical discourse analysis. Studies in English Language and Education, 6(2), 239-250. https://doi.org/10.24815/siele.v6i2.14020

Reisigl, M. \& Wodak, R. (2001). Discourse and discrimination: Rhetorics of racism and antisemitism. London: Routledge.

Utama, G. N., \& Amalia, R. M., (2019). Negative Representation of Assadd's Regime in CNN Online Article. OKARA: Jurnal Bahasa dan Sastra, 13(1).DOI:10.19105/ojbs.v13i1.2262

Utama, G. M., Amalia, R. M., \& Yuliawati, S. (2020). The representation of executed Indonesian migrant workers in The Jakarta Post News articles. Leksika, 14(1).

Wodak, R. \&, \& Meyer, M. (2009). Critical discourse analysis: history, agenda, theory and methodology. In R. Wodak \& M. Meyer (Eds.), Methods of critical discourse analysis. London: Sage. 